предлагаются перспективы дальнейшего развития усовершенствования применения интерактивных технологий в профессиональной подготовке будущих учителей.

Ключевые слова: организационно-педагогические условия, интерактивные технологии, подготовка будущуих учителей $к$ профессиональной деятельности, мотивация учебной деятельности, имитационное моделирование, метод саse-study, активизация познавательной деятельности.

ADOBOVSKA M. V. Organizational-pedagogical conditions and their implementation with the use of interactive technologies for the formation of readiness for the professional activities of future teachers of geography.

The article discusses the organizational and pedagogical conditions for the use of interactive technologies in the preparation of future teachers of geography for professional activities. The definition of the concept of "organizational and pedagogical conditions" in the scientific and pedagogical literature is considered. The organizational and pedagogical conditions of preparing the future teacher of geography for professional activities in the framework of our research are considered in terms of the use of interactive technologies.

The paper suggests the following organizational and pedagogical conditions for training future teachers of geography: the creation of optimal conditions for increasing the motivation of students' learning activities through the use of interactive technologies; the use of interactive technologies to model problematic professional communicative situations; activization of cognitive activity using interactive technologies. Also presented are methods for implementing the above organizational and pedagogical conditions.

The article substantiates the advantages of the use of interactive technologies for the formation of readiness for the professional activities of future teachers of geography and suggests prospects for the further development of improving the use of interactive technologies in the training of future teachers.

Keywords: organizational and pedagogical conditions, interactive technologies, training future teachers for professional activities, motivation of educational activities, simulation modeling, casestudy method, activation of cognitive activity.

DOI: https://doi.org/10.31392/NZ-npu-143.2019.02

УДК [378.091.33-027.22:81’243]

Александрова Л. Г., Гвоздецька К. О.

\title{
РОЛЬОВА ГРА ЯК ЕФЕКТИВНИЙ ЗАСІБ ФОРМУВАННЯ КОМУНІКАТИВНОЇ КОМПЕТЕНТНОСТІ У ДІАЛОГІЧНОМУ МОВЛЕННІ СТУДЕНТІВ 1 КУРСУ МОВНОГО ЗВО
}

Значення рольової гри неможливо вичерпати та оцінити розважсально-рекреативними можсливостями. Ї̈ феномен полягає в тому, що гра, будучи розвагою, відпочинком, має здатність перерости у творчість, у навчання та у модель людських взаємин. У сучасній педагогіиі рольова гра розглядається як специфічний вид людської діяльності, спрямований на відображення навколишньої дійсності, зокрема трудової діяльності дорослих, їх життя $i$ суспільних відносин.

Статтю присвячено проблемі навчання іншомовного діалогічного мовлення за допомогою рольової гри студентів 1 курсу. Визначено поняття рольової гри, ї̈ головні риси, види та процес 
організаиії. Рольова гра придатна для будь-якої роботи з мовою на заняттях з іноземноїмови: у ході рольової гри застосовуються різноманітні граматичні структури, інтонаційні моделі, лексичний матеріал з різних тем. Велика роль приділяється рольовій грі в оволодінні студентами непідготовленим мовленням, бо завдяки їи студенти мають можливість спілкуватися в комунікативних ситуачіях.

Розкрито сутність діалогічного мовлення, висвітлено поняття компетентності в діалогічному мовленні як однієї з найважливіших психологічних особливостей діалогічного мовлення. У статті також характеризуються функціональні типи діалогів та визначаються основні підходи до навчання діалогічного мовлення. Наводяться групи вправ для навчання діалогічного мовлення та обтрунтовується доиільність використання III групи вправ для навчання різних типів діалогу за допомогою рольової гри. Наводяться та описуються вправи з підручника "А way to success: English for university students" для розвитку у студентів уміння иілісного спілкування у формі діалогу.

Ключові слова: рольова гра, діалогічне мовлення, компетентність у діалогічному мовленні, знання, ситуативність, діалог, комунікативна функція, комунікативні вправи.

Значення рольової гри неможливо вичерпати та оцінити розважальнорекреативними можливостями. Ї̈ феномен полягає в тому, що гра, будучи розвагою, відпочинком, має здатність перерости у творчість, у навчання та у модель людських взаємин [8].

У сучасній педагогіці рольова гра розглядається як специфічний вид людської діяльності, спрямований на відображення навколишньої дійсності, зокрема трудової діяльності дорослих, їх життя і суспільних відносин. Характер і зміст гри соціальні за своєю природою і детерміновані конкретними культурними і соціально-економічними умовами життя дитини. Рольова гра, як метод навчання іноземної мови, так само спрямована на відображення навколишньої дійсності і відтворення соціально-культурних відносин іншою мовою [1].

Рольова гра придатна для будь-якої роботи з мовою на заняттях з іноземної мови: у ході рольової гри застосовуються різноманітні граматичні структури, інтонаційні моделі, лексичний матеріал з різних тем. Велика роль приділяється рольовій грі в оволодінні студентами непідготовленим мовленням, бо завдяки їй студенти мають можливість спілкуватися в комунікативних ситуаціях [8].

Гра - це вид діяльності в умовах ситуацій, спрямованих на відтворення і засвоєння суспільного досвіду [2].

Як зазначає Т.М. Науменко, рольова гра - це один із шляхів підвищення ефрективності навчання іноземної мови, зокрема англійської, адже вона допомагає в реалізації методичного принципу - комунікативної спрямованості навчання та мотивує студентів до вивчення іноземної мови [3].

Відомо, що більшості ігор властиві такі головні риси: вільна розвивальна діяльність, яка реалізується лише за бажанням студента, заради задоволення від самого процесу діяльності, а не лише від результату; творчий, більшою мірою імпровізований, активний характер діяльності; емоційна піднесеність діяльності, дух суперництва, конкуренція тощо; наявність прямих чи непрямих правил, що відображають зміст гри, логічну й тимчасову послідовність її розвитку [2].

Рольова гра також має відповідати вимогам, а саме: бути стимулятором студентів до навчання, викликати інтерес і бажання виконувати вправи добре; рольова гра має бути добре підготована та чітко організована; студенти мають повною мірою використовувати лексичний матеріал; викладач має контролювати рольову гру; гра проводиться в доброзичливій атмосфрері, щоб студент почувався 
вільно та впевнено [5].

Педагогічна гра вирізняється суттєвою ознакою - чітко поставленою метою і відповідними їй результатами навчання, які можуть бути обґрунтовані й чітко виділені, а також мають навчально-пізнавальну спрямованість [2].

У методиці навчання іноземних мов прийнято виділяти такі типи ігор :

- мовні ігри (фонетичні, орфографічні, лексичні, граматичні тощо);

- мовленнєві, які сприяють вирішенню певних завдань (створення психологічної готовності студента до мовленнєвого спілкування; забезпечення природної необхідності багаторазового повторення мовного і мовленнєвого матеріалу; тренування студентів у виборі необхідного мовленнєвого варіанта, що $\epsilon$ підготовкою до спонтанного мовлення). До мовленнєвих ігор зазвичай належать ситуаційні та рольові ігри [2].

На заняттях з іноземної мови значного поширення набули рольові ігри, в яких студенти залучаються у змодельовану викладачем ситуацію, що вимагає прийняття рішення на основі аналізу самої ситуації. Рольова гра передбачає розподіл студентів за ролями і розігрування ситуацій спілкування відповідно до заданої теми і ролей [2].

На думку багатьох методистів, процес організації гри складається з трьох етапів: підготовки рольової гри, власне ії проведення і колективного обговорення результатів, тобто завершального. Деякі автори (наприклад, Л. Джонс) виділяють більше етапів: підготовчий етап в аудиторії, підготовчий етап удома, проведення рольової гри, завершальний етап удома, завершальний етап в аудиторії [5].

Рольові ігри поділяються на соціально-побутові $\boldsymbol{i}$ ділові (професійно орієнтовані). Соціально-побутові ігри спрямовані на фрормування навичок і вмінь іншомовного спілкування в соціально-побутовій сфрері, а також на розвиток ініціативності, колективності й відповідальності як суспільно цінних якостей особистості і вдосконалення загальної культури поведінки. Ділові ігри використовуються при навчанні професійно орієнтованого спілкування у школі та університеті [2].

Саме рольова гра з успіхом використовується у формуванні компетентності у діалогічному мовленні. Розглянемо визначення терміну “діалогічне мовлення".

Діалогічне мовлення - це процес мовленнєвої взаємодії двох або більше учасників спілкування. У межах мовленнєвого акту кожен з учасників по черзі виступає як мовець (ініціатор спілкування - адресант) і як слухач (партнер по спілкуванню - адресат) [7].

Водночас, компетентність у діалогічному мовленні (КДМ) - це здатність реалізовувати усномовленнєву комунікацію у фрормі діалогу в життєво важливих для певного віку ситуаціях спілкування та сферах відповідно до комунікативного завдання. Складниками компетентності у діалогічному мовленні $є$ вміння, навички, знання та комунікативні здібності [7].

Ситуативність $€$ однією з найбільш важливих психологічних особливостей діалогічного мовлення. Ситуативним воно $€$ тому, що часто його зміст можна зрозуміти лише з урахуванням тієї ситуації, в якій воно здійснюється [2]. Як зазначає Ю. І. Пассов, самі зовнішні обставини ситуації можуть не бути наявними у момент мовлення, проте вони є у свідомості мовців і обов'язково включені в неї. Слід також зазначити, що у процесі навчання іноземної мови нас цікавлять не будь-які ситуації буденності, а лише такі, що спонукають студентів до мовлення. 
Такі ситуації і називають мовленнєвими або комунікативними, адже вони завжди містять у собі стимул до мовлення [4].

Залежно від провідної комунікативної функції, яку виконує той чи інший діалог, розрізняють функціональні типи діалогів. За результатами досліджень, проведених на різноманітних автентичних навчальних матеріалах англійською, німецькою і російською мовами, показано, що найпоширенішими $є$ основні типи діалогів: діалог-розпитування, діалог-домовленість, діалог - обмін враженнями / думками, діалог - обговорення / дискусія.

Діалог-розпитування може бути одностороннім або двостороннім. У першому випадку ініціатива запитувати інформацію належить лише одному партнеру, у другому - кожному з них.

Уміння вести діалог-домовленість є одним з важливих умінь, яким студенти повинні оволодіти. Цей вид діалогу використовується зазвичай при вирішенні співрозмовниками питання про плани та наміри, він $є$ найбільш посильним для студентів. Після оволодіння цим видом діалогу навчають студентів змішаного типу діалогу: розпитування-домовленості.

Наступним за складністю є діалог - обмін враженнями/думками, метою якого $\epsilon$ виклад свого бачення якогось предмета, події, явища, коли співрозмовники висловлюють свою думку, наводять аргументи для доказу, погоджуються з думкою партнера або спростовують її. При цьому ініціатива ведення бесіди є двосторонньою.

Найскладнішим для оволодіння $€$ діалог-обговорення/дискусія, коли співрозмовники прагнуть виробити якесь рішення, дійти певних висновків, переконати один одного в чомусь.

Особливим функціональним типом діалогу $є$ діалог етикетного характеру. Комунікативна мета таких діалогів - здійснити певну соціальну дію (привітатися та відповісти на привітання, попрощатися, представитися, познайомитися, подякувати, вибачитись, привітати з визначними подіями, святами тощо), передбачену етикетом певної мовленнєвої спільноти [2; 7].

3 погляду профресора філології С. В. Перкаса, навчальні діалоги поділяються на дві групи: 1. Діалоги "рівноправні" (діалоги - обмін інформацією); 2. Діалоги "рольові” (“лікар-пацієнт”, “продавець-покупець”) [6].

Як зазначають методисти, існують різні підходи до навчання діалогічного мовлення, з яких можна виділити два основних. Перший підхід, який має назву “зверху вниз", - має на меті навчання діалогічного мовлення, яке починається зі слухання діалогу-зразка та з його наступним варіюванням, а потім зі створенням власних діалогів в аналогічних комунікативних ситуаціях. Відповідно до другого підходу - "знизу вверх" - це шлях від засвоєння спочатку елементів діалогу, тобто реплік ДЄ, до самостійної побудови діалогу студентами на основі запропонованої навчальної комунікативної ситуації, що не виключає прослуховування діалогівзразків.

До підсистеми вправ для розвитку вмінь діалогічного мовлення методисти включають три групи вправ:

I група - вправи для оволодіння "реплікуванням";

II група - вправи для оволодіння діалогічними єдностями;

III група - вправи для оволодіння різними функціональними типами діалогу .

Нас цікавить саме III група вправ, метою яких $€$ навчити студентів 
створювати на заняттях іноземної мови власні діалоги різних функціональних типів на основі запропонованої їм комунікативної ситуації. Вправи третьої групи комунікативні рецептивно-продуктивні (вищого рівня). Виконуючи вправи цієї групи, викладач допускає лише природні опори, наприклад, театральні або концертні афіші, розклади руху автобусів (літаків, потягів), план, схеми міст/селищ, географрічні карти, слайди, малюнки тощо. Мета виконання вправ цієї групи - розвивати у студентів уміння цілісного спілкування у формі діалогу. Ці вправи можуть проводитися лише в парах, групах/ мікро-групах (по 3-4 студенти) та загальними групами (вся група студентів бере участь в обговоренні, розігрується групова рольова гра тощо) [2].

Варто зазначити, що студенти 1 курсу мовних спеціальностей навчаються за підручником "А way to success: English for university students" [9]. Автори підручника наповнили його різноманітними видами вправ III групи на опанування різних типів діалогу. Кожна вправа з підручника пропонує розіграти діалоги в кожному 3 розділів, опираюсь на лексичний матеріал, поданий безпосередньо в інструкції до вправи або в самому початку розділу. Розглянемо декілька з цих вправ.

Перша вправа на рольову гру з тематичного розділу про виховання дітей для навчання діалогу-обмін враженнями.

\section{STUDENT A \\ 1. Tell Student B that you had a great time working during the holidays and would love to do it again next year. Ask about your partner's experience}

You are two students who worked as au-pair in families abroad over the summer holidays. You are now exchanging your impressions. Make up the dialogue following the instructions.

2. Say there were two children, aged 4 and 11. Tell about their favourite pastimes: the playground activities with the 4-year old, some crafts and indoor games with the 11-year old. Ask Student B how the children in his/ her family liked to spend their free time.

3. Say that the younger child was a real troublemaker at times. Give examples of his/ her bad behaviour.

4. Give some examples of the rules that worked. Ask Student B if he/ she has learnt anything new about the ways to discipline children.

5. Say which ways you think are effective. Talk about the things parents should/ shouldn't do and why.

6. Say that you definitely want and explain why. Ask your friend about his/ her plans.

\section{STUDENT B}

1. Say that you quite liked your family but you had to work really hard. Explain why (more than three children / very young children/ pets to look after etc.) Ask Student A about the children he/ she had to work with.

2. Say the children often invited their friends over. Recall an occasion when you arranged a sleepover/ pyjamas party for them. Give details. Ask Student A about the characters and attitudes of the children in his/ her family.

3. Say you know what student A means and share your memories of the time when the children misbehaved. Say how you handled it. Ask Student A about the ways of disciplining the children in the family (s)he worked for.

4. Say that you discovered some effective ways of encouraging good behaviour. Describe them.

5. Agree and add an example how the parents in your host family got their children to cooperate Ask student A if (s)he wants to try au pair work next year.

6. Reply that you would like to work au pair next summer, but you would prefer a family-with fewer children. 
Ця вправа пропонує студентам розіграти діалог між двома студентами, які працювали за програмою за кордоном. За бажанням, викладач може змінити ролі на студента, який уже працював, та студента, який тільки збирається працювати за цією програмою.

У наступній вправі студентам пропонується розіграти комунікативну ситуацію за картками, де вказані ролі покупця та продавця. Також для зручності студентам надаються приклади реплік для побудови діалогу.

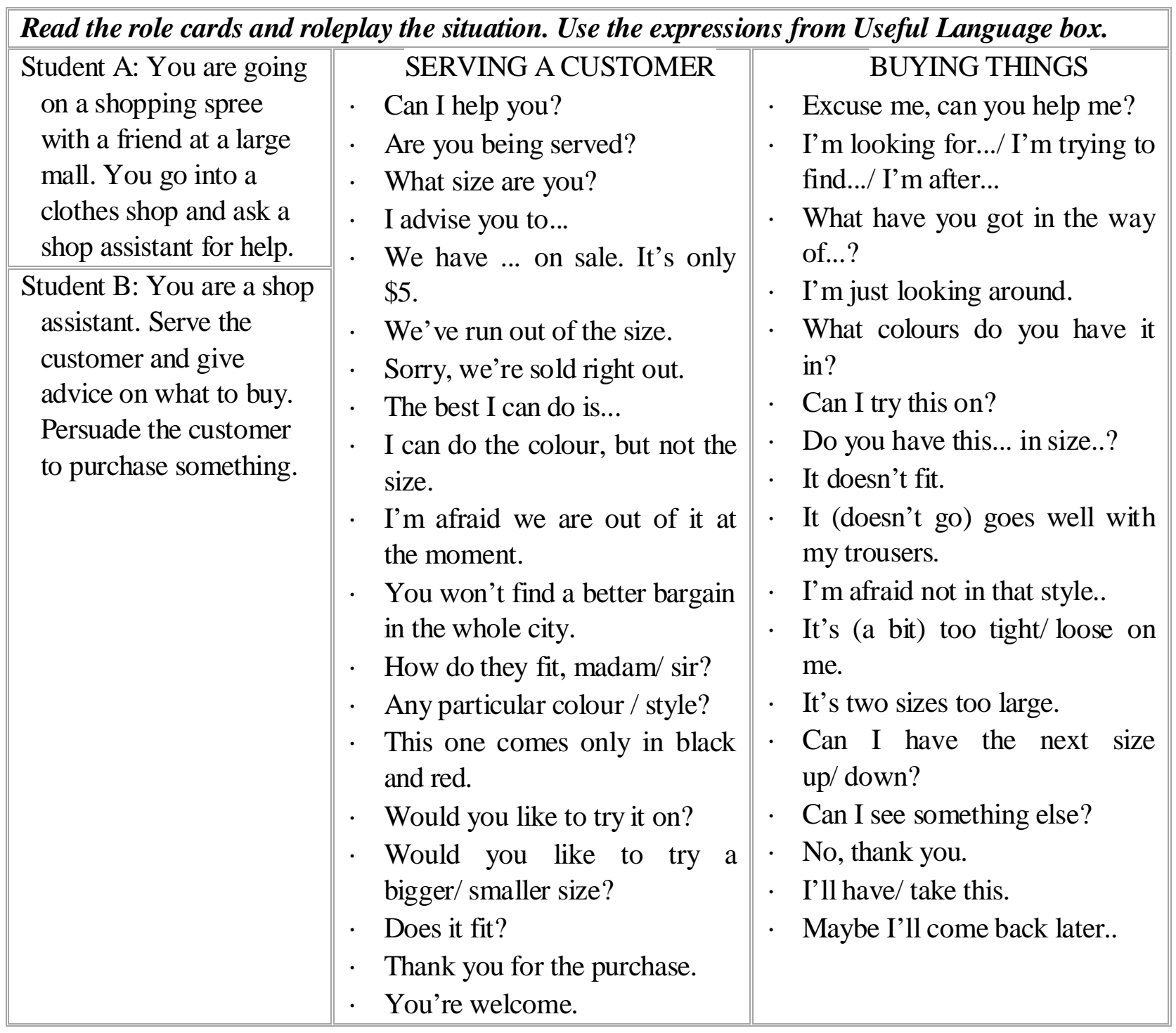

Наступна вправа також пропонує розіграти ситуацію, проте уже ролі дружини та чоловіка. В цій вправі лише подається опис комунікативної ситуації без будь яких опор. У цьому випадку студенти навчаються складати діалогобговорення / дискусію.

Act out a dialogue between a husband and a wife. You have been married for six months, and are discussing your first experience in managing your family budget and the ways to improve their financial situation. 
Наступна вправа пропонує розіграти діалог на тему прибирання будинку. Викладач має змогу сам обрати ролі для студентів, наприклад, мама та син/дочка, старша сестра та брат. У цій вправі студентам чітко подані інструкції для діалогуобговорення.

You are family members who are discussing the forthcoming general cleaning. Make up a dialogue following the instructions.

\section{STUDENT A}

1. Say it's time to do a general cleaning and suggest starting on Saturday.

2. Agree or disagree. Give reasons. Say it is necessary to share responsibilities.

3. Accept the suggestion and say what you are going to do in the kitchen.

4. Remind to buy a new washer to fix the tap and explain why. Mention two more household problems you have.

5. Say what you will do to tidy up and clean the rooms. Explain why it will be a real pleasure after the work in the kitchen.

6. Discuss how you are going to reward yourselves for working hard during the week. Invite Student B to go somewhere at the week- end.

\section{STUDENT B}

1. Suggest doing some work every day during the week so as to have a free weekend.

2. Say you hate cleaning the kitchen and ask Student A to do the work him/herself. In return you will clean the bathroom and the toilet.

3. Add the chores that haven't been mentioned and remind Student A to do them. Say how you will clean the bathroom and the toilet and what things you will have new to buy to prepare for the general cleaning.

4. Suggest your solutions. Come back to the general cleaning and speak about doing the washing and ironing.

5. You will not sit around while the washing machine is working. Specify what you will be doing (plants, dust bin, sorting out footwear).

6. Accept or decline the invitation and explain why.

Ще одна вправа, варта уваги, пропонує скласти діалог-обмін враженнями та розіграти ролі власника будинку та його старого друга. У вправі подано зорові опори та інструкцію. Викладач за бажанням може доповнити та ускладнити завдання студентам.

Act out a dialogue between the owner of the house and his old friend who came to see the renovated house.
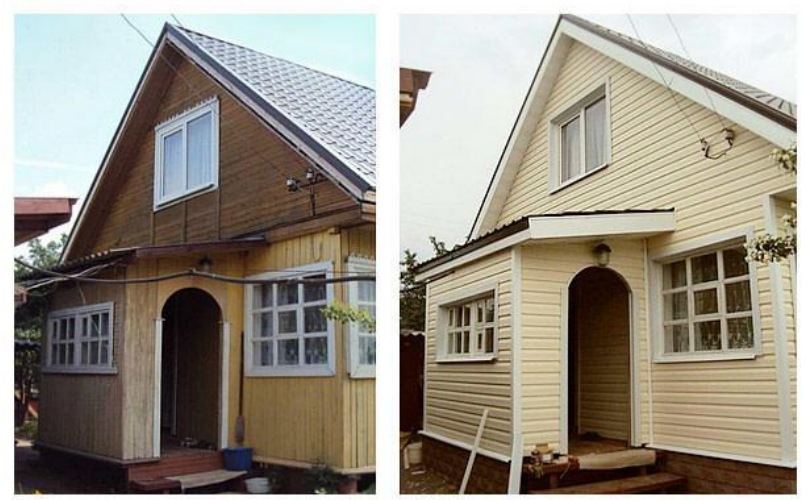
Ще одна вправа, варта уваги, пропонує скласти діалог-обмін думками "ученьдорослий" та діалог-розпитування "учень-друг" на основі інструкції та ідей, поданих у вправі.

A) Your best friend, aged 16, has changed a lot. Share your worries with your relative school teacherlfriend. Describe the problem using the ideas below.

$$
\text { Your friend }
$$

- has become very secretive;

- is always depressed:

- $\quad$ is lagging behind at school;

- $\quad$ is often extremely hostile and sometimes violent

- stayed out all night;

- plays truant or refuses to go to the university/school;

- won't let you know what's going on.

B) Try to help your friend with your advice. What his/her actions should be in this situation?

Загалом, цей посібник для студентів 1 курсу мовних спеціальностей пропонує в кожному розділі відповідно до тематики рольові діалоги різних видів для розігрування різноманітних комунікативних ситуацій в аудиторії.

Отже, студенти мають можливість оволодіти різними функціональними типами діалогів за допомогою підручника "A way to success. English for university students", що сприятиме досягненню мети навчання діалогічного мовлення. Завдання викладача полягає в тому, щоб знайти та використати максимум педагогічних ситуацій, у яких може бути реалізоване прагнення студента до активної пізнавальної діяльності. Викладач повинен постійно вдосконалювати процес навчання, що дає змогу ефективно і якісно засвоювати програмний матеріал студентами. Досить важливо використовувати рольові ігри на заняттях 3 іноземної мови, адже рольова гра додає навчальному спілкуванню комунікативну спрямованість, зміцнює мотивацію вивчення іноземної мови і значно підвищує якість оволодіння нею.

\section{Використана література:}

1. Жук Н. В., Тузова М. К., Ермакова Л. В. Ролевая игра как метод обучения иностранному языку в высшей школе. Актуальные вопросы современной педагогики: материалы IV Междунар. науч. конф. (г. Уфа, ноябрь 2013 г.). Уфа : Лето, 2013. С. 187-191.

2. Методика навчання іноземних мов і культур: теорія і практика : підручник для студ. класичних, педагогічних і лінгвістичних університетів / О. Б. Бігич, Н. Ф. Бориско, Г. Е. Борецька та ін. ; за загальн. ред. С. Ю. Ніколаєвої. - Київ : Ленвіт, 2013. - 590 с.

3. Науменко Т. М. Шляхи активізації мовленнєвої діяльності на уроках англійської мови. Англійська мова та література. 2007. № 4. С. 5-8.

4. Пассов Е. И. Методика как теория и технология иноязычного образования. Кн. 1. Елец : БГУ им. И. А. Бунина, 2010. 543 с.

5. Петренко І. Г. Рольова гра на уроках як елемент комунікативного підходу до вивчення іноземної мови. Англійська мова та література. 2011. № 10. С. 2-5.

6. Рыжкова А. С. Ролевая игра как средство развития умения диалогической речи на среднем этапе обучения иностранному языку (английскому): Выпускная квалификационная работа: 44.03.01; М-во образования и науки Российской Федерации, Российский государственный 
профессионально-педагогический университет; Руководитель Фоминых М. В. Екатеринбург, $2018.83 \mathrm{c}$.

7. Черниш В. В. Навчання іншомовного діалогічного мовлення в аспекті компетентнісного підходу. Іноземні мови. 2012. № 4 (72). С. 11-27.

8. Яковенко Л. І. Рольова гра як активний прийом навчання англійської мови у школі. Іноземні мови. 2006. № 2. C. 16

9. A way to success: English for university students. Year 1 (Teacher's Book) : 2-ге вид., випр. Та доп. / Н. В. Тучина, І. В. Жаковська, Н. О. Зайцева та ін. ; худож.-оформлювач Г. В. Кісель. - Харків : Фоліо, 2015. 400 c.

\section{References:}

[1] Zhuk N. V., Tuzova M. K., Ermakova L. V. (2013). Rolevaya igra kak metod obucheniya inostrannomu yazyiku v vyisshey shkole. Aktualnyie voprosyi sovremennoy pedagogiki : materialyi IV Mezhdunar. nauch. konf. (g. Ufa, noyabr 2013 g.). Уфа : Лето. - С. 187-191.

[2] (2013). Metodyka navchannya inozemnyh mov i kultur: teoriya i praktyka: pidruchnyk dlya stud. klasichnyh, pedagogichnyh i lingvistichnyh universitetiv / O. B. Bigych, N. F. Borisko, G. E. Boretska ta in. ; za zagaln. red. S. Yu. Nikolaevoyi. Kyiv : Lenvit. 590 s.

[3] Naumenko T. M. (2007). Shlyahy aktivizatsiyi movlennevoyi diyalnosti na urokah angliyskoyi movi. Angliyska mova ta literatura. № 4. S. 5-8.

[4] Passov E. I. (2010). Metodika kak teoriya i tehnologiya inoyazyichnogo obrazovaniya. Kn. 1. Elets : BGU im. I. A. Bunina. 543 s.

[5] Petrenko I. H. (2011). Rolova gra na urokah yak element komunikatyvnogo pidhodu do vyvchennya inozemnoyi movy. Angliyska mova ta literatura. № 10. S. 2-5.

[6] Ryizhkova A. S. (2018). Rolevaya igra kak sredstvo razvitiya umeniya dialogicheskoy rechi na srednem etape obucheniya inostrannomu yazyiku (angliyskomu): Vyipusknaya kvalifikatsionnaya rabota: 44.03.01; M-vo obrazovaniya i nauki Rossiyskoy Federatsii, Rossiyskiy gosudarstvennyiy professionalno-pedagogicheskiy universitet; Rukovoditel Fominyih M. V. Ekaterinburg. $83 \mathrm{~s}$.

[7] Chernysh V. V. (2012). Navchannya inshomovnoho dialohichnoho movlennya v aspekti kompetentnistnoho pidkhodu. Inozemni movy. № 4 (72). S. 11-27.

[8] Yakovenko L. I. (2006). Rolova gra yak aktyvnyi pryyom navchannya angliyskoyi movy u shkoli. Inozemni movy. № 2. S. 16.

[9] (2015). A way to success: English for university students. Year 1 (Teacher's Book) : 2 vyd., vypr. ta dop. / N. V. Tuchyna, I. V. Zhakovska, N. O. Zaitseva ta in. ; hudozh.-oformluvach H. V. Kisel. Kharkiv : Folio. $-400 \mathrm{~s}$.

АЛЕКСАНДРОВА Л. Г., ГВОЗДЕЦЬКА К. О. Ролевая игра как эффективное средство формирования коммуникативной компетентности в диалогической речи студентов 1 курса языкового вуза.

Значение ролевой игры не исчерпывается только развлекательно-рекреативными возможностями. Ее феномен заключается в том, что, игра, будучи развлечением, отдыхом, имеет способность перерасти в творчество, в обучение и модель человеческих взаимоотношений. В современной педагогике ролевая игра рассматривается как специфический вид людской деятельности, направленный на отображение окружающей действительности, в частности трудовой деятельности взросльх, их жизни и отношений в обществе.

Статья посвящена проблеме обучения иноязычной диалогической речи с помощьью ролевой игры студентов 1 курса. Ролевая игра подходит для любой работы с языком на занятиях по иностранному языку: в ходе ролевой игры применяются разные грамматические структуры, интонационные модели, лексический материал из разных тем. Большая роль отводится ролевой игре в овладении студентами неподготовленной речи, потому что благодаря ей студенты имеют возможность общаться в коммуникативных ситуачиях.

Дается определение понятия ролевой игры и её видов, раскрывается суть диалогической речи, уточняется понятие компетентности в диалогической речи как одной из важнейтих психологических особенностей диалогической речи. В статье также характеризуются 
функцииональные типы диалогов и определяются основные подходы к обучению диалогической речи. Предложень группь упражнений для обучения диалогической речи и обоснована иелесообразность использования III группы упражснений для обучения различных типов диалога при помощи ролевой игры. Описываются упражнения из учебника "А way to success: English for university students” для развития у студентов умения цеелостного общения в форме диалога .

Ключевые слова: ролевая игра, диалогическая речь, компетентность в диалогической речи, знания, ситуативность, диалог, коммуникативная функиия, коммуникативные упражнения.

ALEKSANDROVA L., HVOZDETSKA K. Role play as an effective way of formation the communicative competence in dialog speeech of the first-year students of higher educational establishment.

The role of a role-playing game can not be exhausted and evaluated by entertaining and recreational possibilities. Her phenomenon lies in the fact that the game, being an amusement, rest, has the ability to grow into creativity, learning and a model of human relationships. In modern pedagogy, role-playing game is regarded as a specific kind of human activity, aimed at reflecting the surrounding reality, in particular the work of adults, their lives and social relations.

The article deals with the problem of teaching the first-year students foreign language dialog speech through the role-play. A role-playing game is suitable for any work with a language in classes from a foreign language: during the role-playing game, various grammatical structures, intonational models, lexical materials on different topics are used. An important role is played by the role play in mastering students with unprepared speech, because thanks to it, students have the opportunity to communicate in communicative situations.

The definition of role-play game is determined; types of role-playing games are given. The definition of the content of dialog speech, the concept of dialog speech competence and one of the most important psychological peculiarities of dialogical speech are revealed. The article also describes the functional types of dialogues and the main approaches to teaching dialogical speech. The groups of exercises for dialogical speech formation are given. The expediency of using the III group of exercises for teaching different types of dialogue through the role-play is substantiated. The exercises from the textbook "A way to success: English for university students" are presented and described for the development of the students' ability to communicate in a form of dialogue.

Keywords: role-play, dialogic speech, competence in dialogic speech, knowledge, situational, dialogue, communicative function, communicative exercises.

DOI: https://doi.org/10.31392/NZ-npu-143.2019.03

УДК 371.212 .7

Бернацька О. В., Комогорова М. І.

\section{СУТНІСТЬ ІНШОМОВНОÏ КОМУНІКАТИВНОÏ КОМПЕТЕНТНОСТІ УЧНІВ ПОЧАТКОВОЇ ШКОЛИ ТА СТРАТЕГІЇ ІІІ ФОРМУВАННЯ}

Зміни, які відбуваються в суспільних відносинах, напрямок на євроінтеграцію вимагають підвищення комунікативної компетенщії школярів, вдосконалення їх мовної підготовки, тому пріоритетної значущості набуло вивчення англійської мови як засобу спілкування. Отже, питання формування комунікативної компетентності стало особливо актуальним. 